\title{
Handbook of Florida Agricultural Laws: Related Non-Crop or Product Agricultural Topics ${ }^{1}$
}

\author{
Michael T. Olexa, lan Alperstein, and Joseph Fischer²
}

\section{Preface}

This handbook is designed to provide an accurate, current, and authoritative summary of the principal Florida laws that directly or indirectly relate to agriculture. It provides a basic overview of the many rights and responsibilities that farmers and farm land owners have under Florida laws. Many readers may value this handbook because it informs them about these rights and responsibilities, and it provides them with good contacts for more detailed information. However, the reader should be aware that because the laws, administrative rulings, and court decisions on which this handbook is based are subject to constant revision, portions of this handbook could become outdated at any time. Many details of cited laws are also left out due to space limitations. 


\section{A Brief Note on Florida Laws and Rule Making}

The Florida laws described in this handbook were passed by the state legislature and have become valid state laws. The appropriate state agency then wrote specific rules based on each law. These rules are what the state agencies use to enforce the law. For most laws in this handbook, that agency is the Department of Agriculture and Consumer Services (DACS). Florida legislated laws, also called statutes, are organized into chapters. A chapter is divided even further into specific statutes. For example, Chapter 601 (Florida Citrus Code) contains dozens of sections covering topics ranging from marketing, inspection standards, and processing to prohibitions on the use of certain chemicals for citrus fruit. Other chapters may deal with a narrower subject and have far fewer sections. As noted above, the specific rules for each of these sections are written by a designated state agency, and generally go into greater detail. You can view the Florida Statutes online at http://www.flsenate.gov/statutes.

\section{Introduction}

This handbook can be used to learn which Florida laws apply to a particular agricultural project or subject, and to find the name, address, and telephone number of a state office that can provide more specific information or services. Created for readers with no prior experience in the law, the handbook is designed as a necessary first step in recognizing which agricultural activities merit special attention because of their implications to agriculture. The handbook also provides an introduction to the crucial agencies and statutes which govern agricultural law.

The online handbook is divided into a Table of Contents, Index, and six fact sheets. The Table of Contents gives general and specific areas of Florida laws related to agriculture and the number of the fact sheet where that topic can be found. The six fact sheets are as follows: FE114, General Agriculture-Related Laws; FE115, Animal Husbandry; FE116, Crops and Products; FE117, Related Non-Crop or Product Agricultural Topics; FE118, Environmental and Conservation Regulations; and FE119, Taxation and Property Rights Related to Agricultural Land. The user can find the specific laws by using either the Table of Contents (FE113) or the Index (FE122).

Below is an example of using the handbook if your area of interest is farming exotic animals such as ostriches.

To use the Table of Contents:

1. Find "Animal Husbandry" in the Table of Contents (FE113).

2. Within the Animal Husbandry area locate "Livestock-Exotic Animals". Follow the link to FE115: Animal Husbandry.

3. In FE115, read the "General Descriptions" and "Related References, Details, and Exceptions" columns for both laws under "Livestock-Exotic Animals". Determine if the information answers the questions or if more information is needed.

4. If the user wants more information regarding the general farming or inspection and slaughter of an exotic animal (e.g., ostriches), locate the appropriate state office telephone number and address. The primary contact agency information is listed at the end of the fact sheet, along with abbreviation information.

To use the Index:

Look up "ostriches" in the Index (FE122). The index leads the reader to the location for information about the culture and inspection/slaughter of ostriches. Follow steps 3 and 4 above to find the contact information.

\section{Division of the Tables}

The table in each fact sheet has five columns of information. The first column, "Statute / Law (description)," either provides the law's name or a general description when no name is available. The second column, "Florida Statute Number", lists either a chapter number when an entire chapter relates to a particular topic, a range of sections, or a single 
specific section. At times, a single chapter number may have many more laws than a range. For example, sections 593.101 to 593.117 cover a narrower field, the control of cotton boll weevil, than the larger Chapter 601 on citrus fruit. The chapter and section number in all columns are presented without the typical abbreviations or symbols.

Columns 3 and 4 provide brief descriptions and related references, details, and exceptions. This information is highly condensed. As such, not all information is provided. The authors have attempted to include the most relevant aspects of each listed law. Additional information can be obtained by contacting the offices noted in the final column, "Primary Contact Agencies." As noted above, the primary contact information is listed at the end of the fact sheet. The reader will find that the state and federal agencies are unquestionably the best targets for specific questions, as they are in close touch with both the formal and practical considerations of the areas that they regulate.

This publication can be improved with your ideas and suggestions. Comments regarding any areas which may have been omitted, but deserve inclusion, are particularly valuable. Reader feedback is a necessary ingredient to complete any successful future editions. Please send your comments or suggestions to:

Michael T. Olexa

Director, Agricultural Law Center

Food and Resource Economics Department

Post Office Box 110240

University of Florida

Gainesville, FL 32611-0240

Fax (352) 392-9898 


\begin{tabular}{|c|c|c|c|c|}
\hline \multicolumn{5}{|c|}{ IV. Florida Agricultural Laws: Related Non-Crop or Product Agricultural Topics } \\
\hline $\begin{array}{l}\text { Statute / Law } \\
\text { (description) }\end{array}$ & $\begin{array}{l}\text { Florida } \\
\text { Statute } \\
\text { Number }\end{array}$ & General Description & $\begin{array}{l}\text { Related References, Details, } \\
\text { and Exceptions }\end{array}$ & $\begin{array}{l}\text { Primary } \\
\text { Contact } \\
\text { Agencies }\end{array}$ \\
\hline \multicolumn{5}{|c|}{ A. Labor Law } \\
\hline $\begin{array}{l}\text { Farm Labor } \\
\text { Registration Law }\end{array}$ & $\begin{array}{l}450.27- \\
450.38\end{array}$ & $\begin{array}{l}\text { Establishes duties of a farm } \\
\text { labor contractor, sets up } \\
\text { voluntary training programs, } \\
\text { and requires examination and } \\
\text { registration of farm labor } \\
\text { contractors. }\end{array}$ & $\begin{array}{l}\text { Requires contractors to post } \\
\text { terms/conditions of employment, } \\
\text { pay workers promptly, maintain } \\
\text { records, and comply with all labor } \\
\text { laws (450.33). See 2004-64, } \\
\text { section 20, establishing } 450.39 \text {; a } \\
\text { farm labor contractor cannot } \\
\text { require farm labors to purchase } \\
\text { goods or services solely from the } \\
\text { contractor, nor can the contractor } \\
\text { charge more than reasonable } \\
\text { costs for commodities. } 450.28 \\
\text { distinguishes between major and } \\
\text { minor violations; a major violation } \\
\text { is one that significantly threatens or } \\
\text { causes physical or economic harm, } \\
\text { resulting in harsher penalties. See } \\
2004-64 \text {, section } 13 \text {, amending } \\
450.31 \text {, which expanded the } \\
\text { reasons that a farm labor } \\
\text { contractor's certificate of } \\
\text { registration can be revoked. } \\
\text { DBPR's Division of Professions is } \\
\text { responsible for farm and child labor } \\
\text { laws (FLCF handles compliance). } \\
\text { See Florida Agricultural Safety Act } \\
\text { (487.2011-487.2071). }\end{array}$ & $\begin{array}{l}\text { DBPR } \\
\text { FLCF }\end{array}$ \\
\hline Child Labor Law & $\begin{array}{l}450.001- \\
450.161\end{array}$ & $\begin{array}{l}\text { Establishes limitations on the } \\
\text { employment of children. }\end{array}$ & $\begin{array}{l}\text { Allows minors of any age to be } \\
\text { employed in domestic or farm work } \\
\text { in connection with their own homes } \\
\text { or farm/ranch on which they live or } \\
\text { in herding, tending, and managing } \\
\text { livestock during non-school hours } \\
(450.021) \text {. Minors } 15 \text { years old or } \\
\text { younger are generally prohibited } \\
\text { from hazardous occupations such } \\
\text { as working with power-driven } \\
\text { machinery or lifting equipment. } \\
\text { However, they may operate farm } \\
\text { tractors under close supervision of } \\
\text { their parents or the farm operator, } \\
\text { providing minor has completed } \\
\text { training course and is certified in } \\
\text { tractor operation (450.061). }\end{array}$ & $\begin{array}{l}\text { DBPR } \\
\text { FLCC }\end{array}$ \\
\hline
\end{tabular}




\begin{tabular}{|c|c|c|c|c|}
\hline \multicolumn{5}{|c|}{ IV. Florida Agricultural Laws: Related Non-Crop or Product Agricultural Topics } \\
\hline $\begin{array}{l}\text { Statute / Law } \\
\text { (description) }\end{array}$ & $\begin{array}{l}\text { Florida } \\
\text { Statute } \\
\text { Number }\end{array}$ & General Description & $\begin{array}{c}\text { Related References, Details, } \\
\text { and Exceptions }\end{array}$ & $\begin{array}{l}\text { Primary } \\
\text { Contact } \\
\text { Agencies }\end{array}$ \\
\hline $\begin{array}{l}\text { Law regarding } \\
\text { migrant labor } \\
\text { camp or } \\
\text { residential } \\
\text { migrant } \\
\text { housing }\end{array}$ & $\begin{array}{l}381.008- \\
381.00897\end{array}$ & $\begin{array}{l}\text { Requires permit to operate } \\
\text { migrant worker housing, and } \\
\text { provides for rule making by } \\
\text { DCF to protect health and } \\
\text { safety of migrant farm } \\
\text { workers. }\end{array}$ & & DCF \\
\hline $\begin{array}{l}\text { Law regarding } \\
\text { migrant labor }\end{array}$ & $\begin{array}{l}450.181- \\
450.191\end{array}$ & $\begin{array}{l}\text { Sets up legislative and } \\
\text { advisory committees to deal } \\
\text { with migrant labor issues. } \\
\text { Authorizes Governor to } \\
\text { execute an interstate migrant } \\
\text { labor compact. }\end{array}$ & $\begin{array}{l}\text { Authorizes Governor to appoint } \\
\text { Florida members to the Interstate } \\
\text { Migrant Labor Commission } \\
(450.261) \text {. }\end{array}$ & DCF \\
\hline \multicolumn{5}{|c|}{ B. Commercial Feed and Foodstuffs } \\
\hline $\begin{array}{l}\text { Florida } \\
\text { Commercial } \\
\text { Feed Law }\end{array}$ & 580 & $\begin{array}{l}\text { Establishes the law regulating } \\
\text { the registration of non-retail } \\
\text { commercial feed distributors, } \\
\text { and the labeling, laboratory } \\
\text { certification, inspection, } \\
\text { prohibitions, and penalties } \\
\text { regarding commercial feeds. }\end{array}$ & $\begin{array}{l}\text { Prohibits adulteration, } \\
\text { misbranding, and other acts } \\
\text { (580.071; } 580.081 ; 580.112) \text {, } \\
\text { provides for penalties ( } 580.121) \text {, } \\
\text { and provides that certain penalties } \\
\text { are payable to consumers } \\
\text { [(80.131). The law's labeling } \\
\text { requirement does not apply to } \\
\text { feeds made according to } \\
\text { customer's formula, to feeds } \\
\text { distributed in vertically integrated } \\
\text { poultry operations, or to feeds } \\
\text { made or distributed by a } \\
\text { cooperative to its members } \\
\text { (580.051(1)). However, feed } \\
\text { distributed by an integrated poultry } \\
\text { operation or by a cooperative to its } \\
\text { members must be labeled } \\
\text { according to FDA requirements } \\
\text { (580.051(3))]. }\end{array}$ & $\begin{array}{l}\text { BFSF } \\
\text { DACS }\end{array}$ \\
\hline \multicolumn{5}{|c|}{ C. Fertilizers } \\
\hline $\begin{array}{l}\text { Laws regarding } \\
\text { the use of } \\
\text { fertilizers }\end{array}$ & 576 & $\begin{array}{l}\text { Establishes law regulating the } \\
\text { registration of fertilizer } \\
\text { manufacturers, and licensing, } \\
\text { labeling, inspection, and use } \\
\text { of fertilizers. }\end{array}$ & $\begin{array}{l}\text { Irrigation systems that apply } \\
\text { fertilizer must be equipped with } \\
\text { proper anti-siphon devices } \\
\text { (576.087). Other prohibited acts } \\
\text { and stop-sales, seizures, and } \\
\text { penalties are described } \\
(576.101-576.181) .\end{array}$ & $\begin{array}{l}\text { BFSF } \\
\text { DACS }\end{array}$ \\
\hline
\end{tabular}




\begin{tabular}{|c|c|c|c|c|}
\hline \multicolumn{5}{|c|}{ IV. Florida Agricultural Laws: Related Non-Crop or Product Agricultural Topics } \\
\hline $\begin{array}{l}\text { Statute / Law } \\
\text { (description) }\end{array}$ & $\begin{array}{l}\text { Florida } \\
\text { Statute } \\
\text { Number }\end{array}$ & General Description & $\begin{array}{l}\text { Related References, Details, } \\
\text { and Exceptions }\end{array}$ & $\begin{array}{l}\text { Primary } \\
\text { Contact } \\
\text { Agencies }\end{array}$ \\
\hline $\begin{array}{l}\text { Nitrogen and } \\
\text { phosphorus } \\
\text { findings and } \\
\text { intent }\end{array}$ & 576.045 & $\begin{array}{l}\text { Establishes provisions to } \\
\text { improve fertilizer management } \\
\text { programs as part of effort to } \\
\text { reduce nitrogen and } \\
\text { phosphorus levels in } \\
\text { groundwater and drinking } \\
\text { water. }\end{array}$ & $\begin{array}{l}\text { Limits liability for nitrogen and } \\
\text { phosphorus contamination of } \\
\text { water provided owner/leaseholder } \\
\text { follows best management practices } \\
\text { for fertilizer application or other } \\
\text { measures adopted by DACS. } \\
\text { Authorizes government agencies in } \\
\text { conjunction with affected farming } \\
\text { groups to adopt specific rules and } \\
\text { procedures. Subsections (1), (2), } \\
\text { (3), (4), and (6) expire on } \\
\text { December } 31,2012 ; \text { remaining } \\
\text { subsections (5) and (7) expire on } \\
\text { December } 31,2017 \text { (580.045(8)). }\end{array}$ & $\begin{array}{l}\text { DACS } \\
\text { DEP } \\
\text { OAWP }\end{array}$ \\
\hline \multicolumn{5}{|c|}{ D. Pesticides and Pest Control } \\
\hline $\begin{array}{l}\text { Florida } \\
\text { Pesticide Law }\end{array}$ & $\begin{array}{l}487.011- \\
487.175\end{array}$ & $\begin{array}{l}\text { Establishes law regulating } \\
\text { labeling, distribution, sale, } \\
\text { proper use, and registration of } \\
\text { pesticides. Designates a class } \\
\text { of more injurious pesticides as } \\
\text { "restricted-use" pesticides } \\
\text { (487.042). Prohibits improper } \\
\text { sales and unlicensed uses of } \\
\text { restricted-use pesticides } \\
\text { (487.031). Allows claims for } \\
\text { damages/injury from others' } \\
\text { pesticide applications, but } \\
\text { requires claims within } 48 \\
\text { hours of incident (487.159). }\end{array}$ & $\begin{array}{l}\text { "Pest" is defined as an insect, } \\
\text { rodent, nematode, plant, or other } \\
\text { organism determined to be a pest } \\
\text { by EPA or DACS. Pesticide use is } \\
\text { also controlled by the Mosquito } \\
\text { Control Chapter (388), and by } \\
\text { Structural Pest Control Act (482), } \\
\text { which deals with lawn and home } \\
\text { pest control. Aerial applicators } \\
\text { licensed by DACS to apply } \\
\text { pesticides must meet all applicable } \\
\text { FAA and DOT requirements, and } \\
\text { must show proof of liability } \\
\text { insurance and surety bond } \\
\text { (486.046). Provides certain penalty } \\
\text { exemptions for engaging in } \\
\text { prohibited acts and violations of } \\
\text { the law (487.081). Effective } \\
\text { January } 1,2009, \text { pesticide } \\
\text { registration needs to be renewed } \\
\text { every two years ( } 487.041(2) \text { ). }\end{array}$ & DAES \\
\hline $\begin{array}{l}\text { Anti-siphon } \\
\text { requirements for } \\
\text { irrigation } \\
\text { systems }\end{array}$ & 487.064 & $\begin{array}{l}\text { Requires irrigation systems } \\
\text { and water supply lines to } \\
\text { pesticide mixing-loading } \\
\text { equipment to have anti-siphon } \\
\text { devices to prevent backflow of } \\
\text { pesticide. }\end{array}$ & $\begin{array}{l}\text { DACS has set forth rules for the } \\
\text { specific requirements of the } \\
\text { anti-siphon device, regarding } \\
\text { design and operation. See } \\
\text { "Fertilizer" section. }\end{array}$ & $\mathrm{BCM}$ \\
\hline
\end{tabular}




\begin{tabular}{|c|c|c|c|c|}
\hline \multicolumn{5}{|c|}{ IV. Florida Agricultural Laws: Related Non-Crop or Product Agricultural Topics } \\
\hline $\begin{array}{l}\text { Statute / Law } \\
\text { (description) }\end{array}$ & $\begin{array}{l}\text { Florida } \\
\text { Statute } \\
\text { Number }\end{array}$ & General Description & $\begin{array}{c}\text { Related References, Details, } \\
\text { and Exceptions }\end{array}$ & $\begin{array}{l}\text { Primary } \\
\text { Contact } \\
\text { Agencies }\end{array}$ \\
\hline $\begin{array}{l}\text { Florida } \\
\text { Agricultural } \\
\text { Work Safety } \\
\text { Act }\end{array}$ & $\begin{array}{l}487.2011- \\
487.2071\end{array}$ & $\begin{array}{l}\text { Protects agricultural farm } \\
\text { workers employed in Florida } \\
\text { from agricultural pesticides } \\
\text { and provides information to } \\
\text { them about pesticides they } \\
\text { may come in contact with } \\
\text { while working. }\end{array}$ & $\begin{array}{l}\text { Adopts EPA pesticide labeling laws } \\
\text { (487.2041). Employers must make } \\
\text { pesticide information available to } \\
\text { workers if they may be exposed to } \\
\text { pesticides while working or if } \\
\text { workers enter areas treated with } \\
\text { pesticides within the last } 30 \text { days } \\
\text { (487.2051). It is prohibited for } \\
\text { employers to fail to make } \\
\text { information available to workers or } \\
\text { to retaliate against workers who } \\
\text { exercise their rights (487.2061). } \\
\text { Process for filing violations with } \\
\text { DACS is found under } 487.2042 \text {. }\end{array}$ & $\begin{array}{l}\text { DACS } \\
\text { EPA }\end{array}$ \\
\hline \multicolumn{5}{|c|}{ E. Seeds } \\
\hline $\begin{array}{l}\text { Florida Seed } \\
\text { Law }\end{array}$ & 578 & $\begin{array}{l}\text { Establishes the basic law } \\
\text { regarding the registration of } \\
\text { suppliers and the labeling of } \\
\text { seeds intended for sowing or } \\
\text { planting. }\end{array}$ & $\begin{array}{l}\text { Establishes penalties for violations } \\
\text { of the chapter ( } 578.13 ; 578.181) \text {. } \\
\text { Requires seed dealers to keep } \\
\text { records of seed sales for } 3 \text { years } \\
(578.23) \text {. }\end{array}$ & DAES \\
\hline
\end{tabular}

\begin{tabular}{|ll|}
\hline \hline & \multicolumn{1}{c}{ Contact Agencies } \\
\hline BCM & Bureau of Compliance Monitoring (DACS) \\
BFSF & Bureau of Feed, Seed, and Fertilizer Laboratories (DACS) \\
DACS & Florida Department of Agriculture and Consumver Services \\
DAES & Division of Agricultural Environmental Services \\
DBPR & Department of Business and Professional Regulations \\
DCF & Department of Children and Families (or contact local DCF) \\
DEP & Florida Department of Environmental Protection \\
EPA & Environmental Protection Agency \\
FLCF & Bureau of Compliance, Farm Labor Program (DBPR) \\
FLCC & Bureau of Compliance, Child Labor Program (DBPR) \\
OAWP & Office of Agricultural Water Policy (DACS) \\
\hline Burea of Compliance Monitoring (BCM) \\
3125 Conner Boulevard, Suite F \\
Tallahassee, FL 32399-1650 \\
(850) 488-8731 [voice] \\
http://www.flaes.org/complimonitoring/index.html \\
\hline \hline
\end{tabular}




\begin{tabular}{|c|}
\hline Contact Agencies \\
\hline $\begin{array}{l}\text { Bureau of Feed, Seed, and Fertilizer Laboratories (BFSF) } \\
3125 \text { Conner Boulevard } \\
\text { Tallahassee, FL 32399-1650 } \\
\text { (850) 488-9095 [voice] } \\
\text { http://www.flaes.org/aes-fsflab/index.html }\end{array}$ \\
\hline $\begin{array}{l}\text { Florida Department of Agriculture and Consumer Services (DACS) } \\
\text { Office of the Commissioner } \\
\text { The Capitol } \\
\text { Tallahassee, FL } 32399-0800 \\
\text { (850) 488-3022 [voice] } \\
\text { E-mail: commissioner@doacs.state.fl.us }\end{array}$ \\
\hline $\begin{array}{l}\text { Division of Agricultural Environmental Services (DAES) } \\
\text { Bureau of Compliance Monitoring } \\
3125 \text { Conner Boulevard, Suite F } \\
\text { Tallahassee, FL 32399-1650 } \\
\text { (850) 488-8731 [voice] } \\
\text { http://www.flaes.org/complimonitoring/index.html }\end{array}$ \\
\hline $\begin{array}{l}\text { Florida Department of Business and Professional Regulation (DBPR) } \\
\text { DBPR Customer Contact Center } \\
1940 \text { North Monroe Street } \\
\text { Tallahassee, FL 32399-1027 } \\
\text { (850) 487-1395 } \\
\text { Call.Center@dbpr.state.fl.us } \\
\text { http://www.state.fl.us/dbpr/ }\end{array}$ \\
\hline $\begin{array}{l}\text { Farm Labor Program (FLCF) } \\
\text { Bureau of Farm Labor } \\
\text { Post Office Box } 1698 \\
\text { Tallahassee, FL 32302-1698 } \\
\text { (850) 488-3131 [voice] } \\
\text { Call.Center@dbpr.state.fl.us } \\
\text { http://www.myflorida.com/dbpr/reg/farm/index.shtml } \\
\text { Child Labor Program (FLCC) } \\
\text { Bureau of Child Labor } \\
\text { 1940 North Monroe Street } \\
\text { Tallahassee, FL 32399-1044 } \\
\text { (800) 226-2536 [toll-free, voice] } \\
\text { (850) 488-3131 [voice] } \\
\text { Call.Center@dbpr.state.fl.us (Include "Child Labor"in subject line) } \\
\text { http://www.myflorida.com/dbpr/reg/childlabor/index.shtml }\end{array}$ \\
\hline $\begin{array}{l}\text { Florida Department of Children and Families (DCF) } \\
\text { Office of the Secretary } \\
1317 \text { Winewood Boulevard, Building 1, Room } 202 \\
\text { Tallahassee, FL 32399-0700 } \\
\text { (850) 487-1111 [voice] } \\
\text { (850) 922-2993 [fax] } \\
\text { http://www.myflorida.com/cf_web/ }\end{array}$ \\
\hline
\end{tabular}




\begin{tabular}{|c|}
\hline Contact Agencies \\
\hline 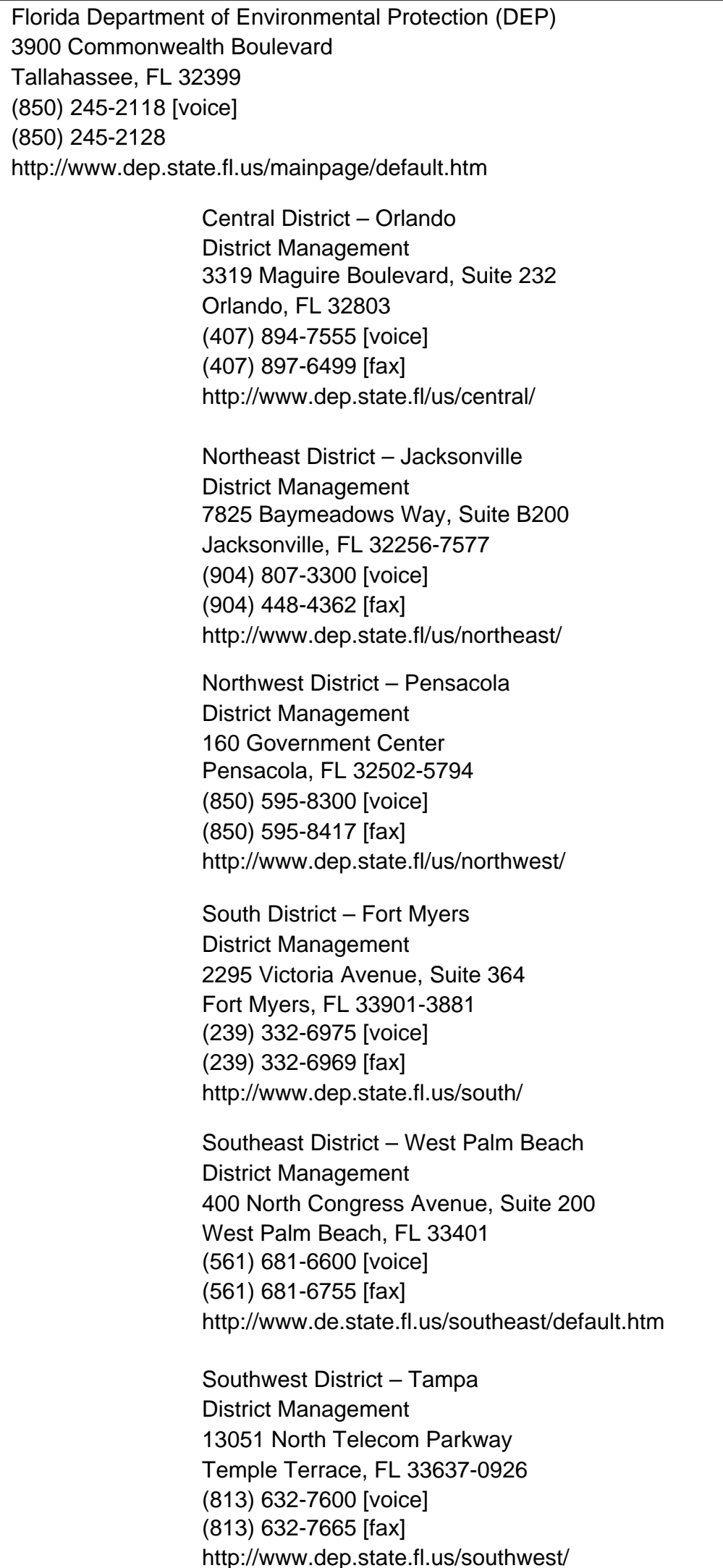 \\
\hline
\end{tabular}




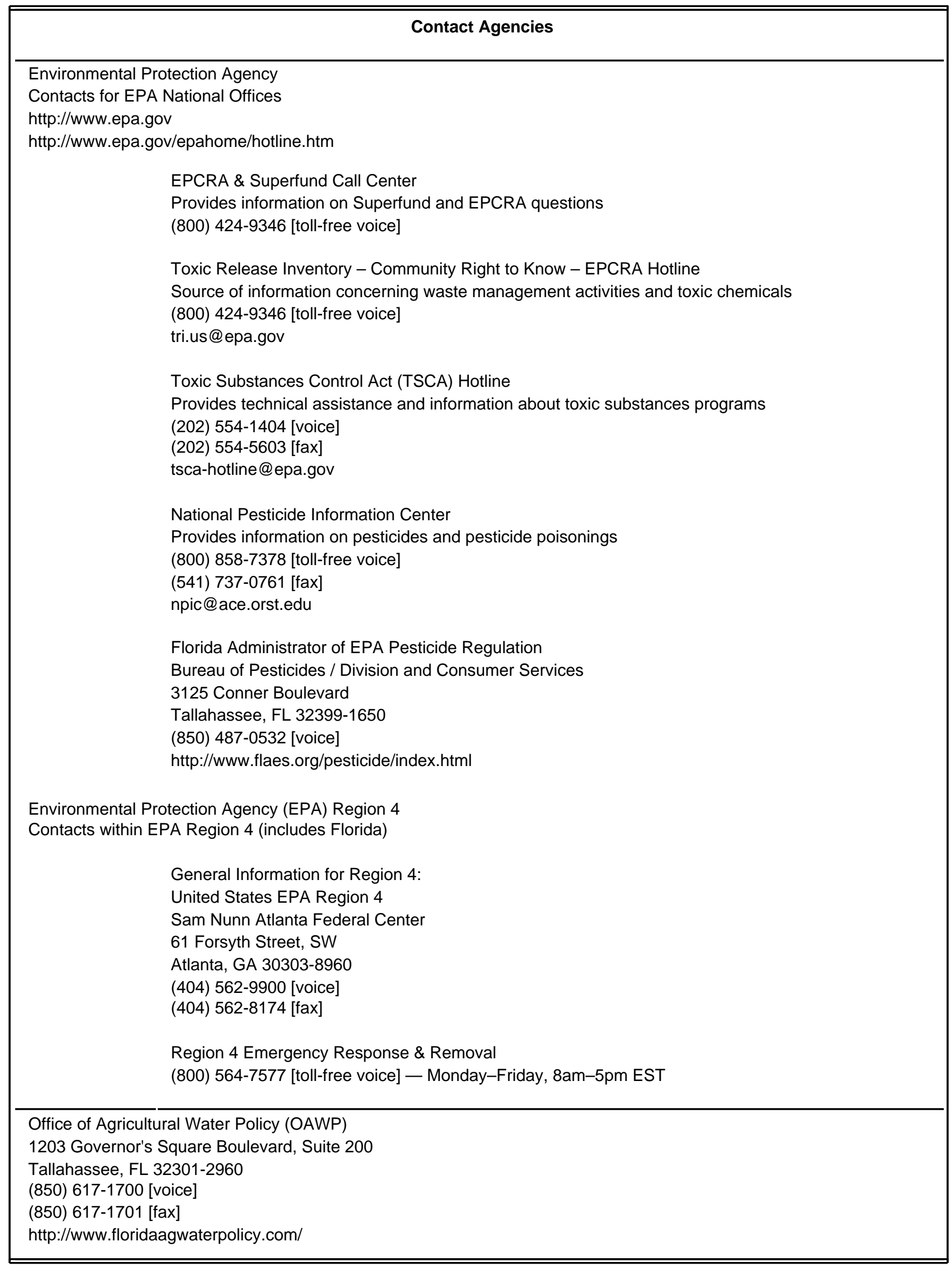

